HoST - Journal of History of Science and Technology

Vol. 15, no. 2, Dec 2021, pp. 121-148

10.2478/host-2021-0015

SPECIAL ISSUE

GLOBAL FLORA: MASTERING EXOTIC PLANTS (EIGHTEENTH - NINETEENTH

CENTURIES)

\title{
Paraguay Natural llustrado by José Sánchez Labrador SJ: Between the American Experience and Exile
}

\author{
Eliane Cristina Deckmann Fleck \\ Universidade do Vale do Rio dos Sinos - Unisinos, Brazil \\ efleck@unisinos.br
}

\begin{abstract}
This paper analyzes the work Paraguay Natural Ilustrado and discusses the impact that the American experience and the later exile in Italy had in the trajectory and intellectual production of its author, Jesuit priest José Sánchez Labrador. The four volumes have evidence of the scientific advancements in Europe in the second half of the eighteenth century, due to his contact with other exiled Jesuits and the collection of the Library of Ravenna, along with his observations of American nature and the indigenous populations of the Jesuit Province of Paraguay. His experience for thirty-four years in the Americas, and later in exile, unmistakably are present in Paraguay Natural. It contributes significantly to the reconstitution of the circulation process and appropriation of botanical knowledge and of the intellectual environment in which the Jesuit brothers and priests were in, both in the missions among the natives in America, as well as in Europe in their exile.
\end{abstract}

Keywords: Paraguay Natural Ilustrado; José Sánchez Labrador; American nature; botanical knowledge circulation; exile

(C) 2021 Eliane Cristina Deckmann Fleck.

This is an open access article licensed under the Creative Commons Attribution-NonCommercial-NoDerivs License (https://creativecommons.org/licenses/by-nc-nd/4.0/). 


\section{Introduction}

Despite a selective assimilation of ideas dear to the Enlightenment, some priests and brothers of the Society of Jesus produced remarkable scientific knowledge based on observation and experience and also on the productive dialogue they maintained with modern science and philosophy. ${ }^{1}$ This singular position was translated into the expressive number of works written by members of the order, such as Historias Naturales (Natural Histories) and Materias Médicas (Medical Subjects), ${ }^{2}$ whose analysis allows the reconstitution of the scientific knowledge appropriated by it, disseminated and produced throughout the seventeenth century and in the first half of the eighteenth century. ${ }^{3}$ In addition to this peculiar condition of the Society of Jesus, and given the conditions in which the colonial advance over American lands took place, added to the instruction, personality and talents of each missionary and the isolation to which many of them were subjected, it is also necessary to consider that many of these

\footnotetext{
${ }^{1}$ In relation to this aspect, Antonella Romano observes that "the natural sciences, from Botany to Zoology, which did not belong to the initial intellectual baggage that the missionary possessed ...., indicate the mobilization of new scientific practices. In all these areas, the Jesuits have produced works, reports, made observations, sent plants, drawings, since the early days of the missions: the Ibero-American world has not only been the limit for these operations, it has aroused them and made the Missionaries of the Society central agents of the project of inventory and world domination of the modern age." Antonella Romano, "Actividad científica y Nuevo Mundo: el papel de los jesuitas en el desarrollo de la modernidad en Iberoamérica," in Los Jesuitas y la modernidad en Iberoamérica (1549-1773), eds. Manuel Marzal and Luis Bacigalupo, 56-71 (Lima: Fondo Editorial de la Pontificia Universidad Católica del Perú, 2007), 64-5.

${ }^{2}$ The works of Natural History written by Jesuit priests in the eighteenth century contributed decisively to "the creation of an American scientific knowledge, based on the observation of the facts and on an interpretation that was decidedly intended to be objective," which made them oppose a knowledge produced about the New World "that lacked the basis of observation and of experience" and, especially, that supported the New World's natural inferiority thesis. Kristin Huffine, "Raising Paraguay from Decline: Memory, Ethnography, and Natural History in the Eighteenth-Century Accounts of the Jesuit Fathers" in El saber de los jesuitas, historias naturales y el Nuevo Mundo, eds. Luis Millones Figueroa and Domingo Ledezma, 279-302 (Madrid: Iberoamericana, 2005).

${ }^{3}$ For Figueroa and Ledezma, throughout the eighteenth century, the Jesuits gradually incorporated and assimilated the ideas and methods of studying Enlightenment, but this did not mean "an absolute rejection of the study of nature inspired by the wonder and awe infused by the complexities and mysteries of the American natural world." Thus, the production of knowledge based on observation and experience so dear to the Jesuits "did not overshadow the fascination for the mysteries of nature." Luis Millones Figueroa and Domingo Ledezma, "Introducción: los jesuitas y el conocimiento de la naturaleza americana, in Figueroa and Ledezma," El saber de los jesuitas, 22. This posture, in a way, explains the ambiguous place that the Jesuits occupied in the history of modern science, since sometimes a small contribution to scientific progress is attributed to them. According to Sheila J. Rabin, "Early Modern Jesuit Science. A Historiographical Essay," Journal of Jesuit Studies 1, no. 1 (2014): 88-104, on 90 , sometimes the scientific interest of the members of the order shifts to an activity subordinated to religious goals, valuable only insofar as it contributed to the evangelizing mission. Mark A. Waddel, Jesuit Science and the End of Naturés Secrets (Burlington: Ashgate, 2015), 3-4.
} 
records suffered undeniable influences from the experiences—strongly marked by intercultural exchanges— that these priests and brothers lived. ${ }^{4}$

For Miguel de Asúa, the abundance and variety of scientific activities developed in the Jesuit missions installed in the territory of the River Plate and in a region of historic Paraguay (i.e., the Jesuit Province of Paraguay) refute the false idea "that the colonial River Plate was a wasteland as far as scientific culture is concerned." This same author, in his book Science in the Vanished Arcadia. Knowledge of Nature in the Jesuit Missions of Paraguay and Río de la Plata (2014), points out that, if on the one hand, Jesuit science can be characterized as an expression of the Baroque culture that had its peak during the modern period-and therefore identified with the missionary objectives of the Society of Jesus-, on the other hand, Jesuit science in the colonial River Plate was configured as an articulation of European forms of thought with native meanings and categories. ${ }^{6}$

This perception seems to justify the proposition of studies on the destination of the manuscripts, especially those that still remain unpublished, which were written by priests and brothers of the order, in the seventeenth and eighteenth centuries, and of the collections of the Jesuit libraries soon after the expulsion of the Society of Jesus from the Hispanic America, in 1767. An analysis of the inventories of the order's goods, for example, points to the presence of books, ${ }^{7}$ medicines, utensils and instruments in the colleges and reductions of the Society of

\footnotetext{
4 Serge Gruzinski draws attention to the two-way street of cultural and material exchanges that took place in the context of modernity and, above all, to the agency and active participation of local populations in the processes of globalization, insofar as they acted as intermediaries between societies and cultural practices. Serge Gruzinski, As Quatro Partes do Mundo: História de uma Mundialização (Belo Horizonte: Editora UFMG; São Paulo: Edusp, 2014). As for the creation of a collaborative network and exchanges between the author-compiler and other religious or indigenous informants, we consider pertinent what was observed by the organizers of the book Connecting Worlds: Production and Circulation of Knowledge in the First Global Age, which in its introduction emphasize that cooperation can be seen as "a social process where individuals, groups and institutions act in a concerted way to reach common goals. These phenomena involve not only the expected economic outputs of cooperative relations (costs vs. benefits), but also the social attributes of partners and their relations. This behavior is driven by goals, expectations and motivations which imply a collective or dyadic interaction between individuals. Individual motives and beliefs are therefore seen as the basis of cooperation, even if the game established has inevitable social implications. The repercussion of this analysis, when applied to colonial empires, implies a focus on the relationships between colonists and colonized." Amélia Polónia, Fabiano Bracht and Gisele Conceição Connecting Worlds: Production and Circulation of Knowledge in the First Global Age (Newcastle: Cambridge Scholars Publishing, 2018), 9.

5 Miguel de Asúa, "El primer trabajo científico en el Río de la Plata." Comunicación efectuada por el académico titular Dr. Miguel de Asúa en la Sesión Plenaria de la Academia Nacional de Ciencias de Buenos Aires (Presentation made by tenured academic Dr. Miguel de Asúa in the Plenary Session of the National Academy of Science of Buenos Aires), 2013. Available at: http://www.ciencias.org.ar/user/As\%FAa\%20 Primer\%20trabajo\%20cient\%EDfico_MODIFICADO.pdf, Accessed 8 October, 2020.

${ }^{6}$ Miguel de Asúa, Science in the Vanished Arcadia. Knowledge of Nature in the Jesuit Missions of Paraguay and Río de la Plata (Leiden; Boston: Brill, 2014).

7 The Annual Letters prescriptions and works directed to the arts of healing written by Jesuits include
} 
Jesus in Platin America, ${ }^{8}$ revealing that they were, par excellence, spaces for the circulation of knowledge and experimentalism, in which there was both the refutation and the validation of practices and knowledge. ${ }^{9}$

A recent historiographical aspect has been dedicated precisely to reevaluate the performance of the Jesuits in the construction of the so-called modern science, ${ }^{10}$ highlighting the role they

references to classic works of Medicine and Treatises of Surgery, which were part of the collections in the libraries of colleges and reductions of the Society of Jesus. Among them are: Farmacopea, by Palácios; Opera Medica by Hotosmani; two medical volumes by Carlos Muretano; Opera Medica and Diccionario Medico (Medical Dictionary), by Ribera; Cirugía (Surgery), by Robledo; Postemas (Pustules), by López; Medicina (Medicine), by Guadalupe; Cirugia (Surgery), by Vigo; Farmacopea Matricense; Farmacopea, by Ceci; Cirugia (Surgery), by Vigo and Opera Medica, by Syderas. It is worth mentioning that there was a catalog of books that could be sold and sent to the so-called Indias Ocidentales (Western Indies) and which contained works such as Disputaciones de Medicina (Disputations on Medicine), by Garcia; De Corpore humana, by Valverde; Cirugía (Surgery), by Redondo; De morbo gallico, by Duarte Madeira; Cirugía (Surgery), by Borbon; as well as Promptuario (Medical Record), by Remigio and Promptuario (Medical Record), by Salazar. The Library of the University of Córdoba had works such as Tesoro de Medicina (Treasure of Medicine), by Egidio de Villalón; Cirugía Universal (Universal Surgery), by Calvo; El Tratado de todas las enfermedades (The Treatise of all diseases), by Francisco Diaz; Tratado de Medicina (Treatise of Medicine), by Juan Amato; and Los Principios de Cirugia (The Principles of Surgery), by Ayala.

${ }^{8}$ Occupying an area of approximately 3.3 million square kilometers, the Platin America is a region in South America formed by three countries: Argentina, Uruguay and Paraguay, bathed by the hydrographic basin of the Río de la Plata (River Plate). Thus, the designation of Platin America for this region.

9 The importance of the Society of Jesus colleges is highlighted by Antonella Romano, for whom "The Society of Jesus, an exemplary laboratory for the invention of modernity, had to take charge of the debates raised by the 'scientific revolution,' particularly within the framework of the scientific teachings that were developed in its schools. The space of the missions opened the way to other scientific experiences different from those foreseen in the framework of the teaching apostolate. . . . In the IberoAmerican world, as in European spaces, science emerges in the first place in schools, around philosophy courses, in the teaching of mathematics, courses that are not systematically taken within the framework of specialized chairs" Romano, "Actividad científica y Nuevo Mundo," 56-63. See also: Jorge Cañizares Esguerra, Como escribir la historia del Nuevo Mundo: Historiografias, epistemologias e identidades en el mundo del Atlántico del siglo XVIII (México: Fondo de Cultura Económica, 2007).

${ }_{10}$ The thought around the multiple activities carried out by the members of the Society of Jesus - both as religious in charge of villages, reductions and colleges, as well as farm administrators - in charge of the maintenance of Jesuit colleges has always divided the opinions of historians. And for more than four centuries, the order had a negative appreciation caused, to a large extent, by the efficient diffusion of an anti-Jesuit historiography, influenced by Enlightenment thought. About this subject, it is recommended to see more in Jeffrey D. Burson and Jonathan Wright, eds., The Jesuit Suppression in Global Context: Causes, Events, and Consequences (Cambridge: Cambridge University Press, 2015), and in Jonathan Wright, The Jesuits: Missions, Myths and Histories (Glasgow: HarperCollins, 2004). This historiographical tradition altered significantly in the 1990s when a number of studies based on documents from the Society of Jesus archives in Rome and the Americas highlighted the unquestionable role played by the Jesuits in the intellectual history of the Renaissance since the beginnings of the modern era, and their influence on the medical and pharmaceutical knowledge prevailing today. Beatriz Helena Domingues, Tão longe, tão perto: a Ibero-América e a Europa Ilustrada (Rio de Janeiro: Museu da República, 2009), Antonio Barrera-Osorio, Experiencing nature: the Spanish American empire and the early scientific revolution (Austin: University of Texas Press, 2006) and Daniela Bleichmar, Science in the 
played in the creation of knowledge networks and in the formation of a particular epistemology in the eighteenth century, ${ }^{11}$ and emphasizing, above all, the importance of the colleges of the Society installed in the various regions where its members worked. ${ }^{12}$ For Antonella Romano, it is essential to inscribe the activities of the Society of Jesus in the American world, in a reflection on the nature of the order and the missionary apostolate. She reminds us that intellectual activities, and those specifically linked to the sciences, are not constitutive of the Jesuit identity, but a contingent element of it, due to open interpretations of the Ignatian principle of acting in the century. ${ }^{13}$ In their missionary work, Jesuit priests and brothers faced issues that had to be resolved locally, which led to changes in their theological and scientific conceptions, which could not escape the effervescence of contact, as proposed by Zupanov. ${ }^{14}$ In Asúa's point of view, the Jesuits' natural histories have several features, like their affinity with wonders and religious miracles, their hospitality to native languages and their dubiously critical criteria of evidence that made him argue that their works belong to Baroque. In short, their natural histories "were the result of the author's life experience in the tropical forest and as such reveal their preoccupations and interest." ${ }^{\prime 15}$

Spanish and Portuguese empires (1500-1800) (Stanford: Stanford University Press, 2009), among others, question this traditional approach that sees the Society of Jesus as being backward-looking and resistant to change, associated with the medieval catholic and baroque tradition, noting the assimilation of some key_albeit selective and catholic_ideas from the Enlightenment by the Jesuits working in American missions.

${ }_{11}$ The study of the history of science, including non-European spaces, which traditionally are not privileged in the narratives of scientific knowledge production, has enabled the questioning of Western exclusivity in the development of modern science and of the crystallized conception that the so-called world peripheries are limited to receive (and appropriate) the knowledge produced in Europe. The Franco-Indian historian Kapil Raj points out that in these circulation spaces, regardless of their size, practices, techniques and knowledge of different cultures have moved, going through a negotiation process. The result of these meetings generated, not the overlapping of one knowledge over the other or a relationship of center-periphery hierarchy, but the formulation of a new type of knowledge. For Raj, "the resulting interactions [between agents of knowledge, politicians, etc.] are themselves a place for the construction and reconfiguration of knowledge." Kapil Raj, "Além do Pós-colonialismo... e Póspositivismo: Circulação e a História Global da Ciência," Revista Maracanan, no. 13 (2015): 164-75, on 170.

${ }^{12}$ For Miguel de Asúa, "there are enough elements to conclude that . . . since the time of the Jesuits (before their expulsion in 1767) there were episodes and 'modernizing' characters in the River Plate... in the missions an interesting scientific activity was displayed, as evidenced by the cases of the astronomer Buenaventura Suárez . . . and the authors of the 'Historias Naturales Jesuitas del Nuevo Mundo' (Jesuit Natural Histories of the New World) or the manuscripts of Materia Médica. I have been arguing for a long time that in the middle of the eighteenth century the most advanced front of science in the River Plate was located in the missions of historic Paraguay." Miguel de Asúa, La ciencia de Mayo: la cultura cientifica en el Río de la Plata, 1800-1820 (Buenos Aires: Fondo de Cultura Económica, 2010), 192-3.

${ }_{13}$ Antonella Romano, "Las primeras enseñanzas científicas en Nueva España: México entre Alcalá, Mesina y Roma," Takwá, no. 8 (2005): 93-118.

${ }^{14}$ Ines G. Zupanov, Missionary Tropics. The catholic frontier in India (16th-17th centuries) (Ann Arbor: University of Michigan Press, 2005).

${ }^{15}$ Asúa, Science in the Vanished Arcadia, 84. 
During the seventeenth and eighteenth centuries, the scientific project of the Society of Jesus was, effectively, a clear and influential alternative on the European cultural map, as "the most recognized figures of the Jesuit intelligentsia in Europe reflected on the nature of the New World," based on the information they received "from the Jesuit brothers from the periphery," who, in addition to being part of a group that was "qualified and reliable ... around the world," constituted a remarkable network of "travel agents from the Society." 16

For Andrés Prieto, "Despite renewed interest in the scientific activity of the Society of Jesus during the sixteenth and seventeenth centuries, the contributions to the study of nature made by the Jesuits working in the Spanish American missions have received little attention. In this sense, the intellectual activities of the South American Jesuits have had the same historiographical fate as that of early modern Iberian science in general." ${ }^{17}$ The author points out that: "Although the study of nature was not formally a part of the goals or the ministries of the Society of Jesus in South America, the dedication of some of its members to the exploration and research of American nature was a constant during the two hundred years the order was present on the continent. Because of the peculiar relationship the order developed with culture and knowledge, as well as the usefulness that a deeper knowledge of nature had for the missionary enterprise, the superiors of the order in South America encouraged and stimulated these studies; however, despite this constant effort, neither their intellectual practices nor the contributions of South American Jesuit naturalists have gained them more than a marginal position at best in the current debates about early modern science." ${ }^{18}$

Since the first decade of the seventeenth century, many Jesuit missionaries sent to the Americas, concerned with better caring for the sick — to ensure the health of souls and bodies-dedicated themselves to collecting and experimenting with native plants in the vicinity of colleges and the reductions in which they operated. The existence of wards, as well as herbaria and apothecaries in colleges and in Jesuit reductions, can be seen in the Annual Letters, which refer to the application of practices and knowledge of Medicine and Pharmacy, aiming to combat epidemics that affected both Indians and Europeans and to care for the sick people who sought the remedies and the spiritual comfort that only priests could provide.

Counting on the collaboration of indigenous people, who actively played the roles of informants, nurses, midwives and also of copyists, brothers and Jesuit priests-such as Pedro Montenegro, author of Materia Médica Misionera (Missionary Materia Médica) (1710), and Segismund Asperger-installed herbaria and apothecaries, systematized and circulated knowledge and

\footnotetext{
${ }^{16}$ Figueroa and Ledezma, El saber de los jesuitas, 27-8.

17 Andrés Prieto, Missionary Scientists: Jesuit Science in Spanish South America, 1570-1810 (Nashville: Vanderbilt University Press, 2011), 2.

18 Ibid., 10.
} 
practices, through the intense correspondence maintained among themselves or through copies of treaties and prescriptions that circulated between the reductions and the colleges of the Jesuit Provinces of Platin America and those installed in Europe-in particular, with the pharmacy of the Roman College—and also in the East. Some apothecaries—-such as the Colegio San Pablo, in Lima-have, over time, become reference centers, sending medicines—such as Peruvian bezoar, and Mexican ambrosia and cinchona - to establishments of the Society of Jesus in Chile, Paraguay, Argentina, Ecuador, Panama and the Old World, attesting to the intense circulation of procedures and knowledge. ${ }^{19}$

The mentions made by Jesuit brother, Pedro de Montenegro, to Riveiro, Pedro Andrés Mathiolo, Andrés de Laguna and Dioscórides, and the application of some of their assumptions, especially in the first three chapters of Materia Médica Misionera (Missionary Materia Médica), seem to confirm access and reading of these medical reference works by the Jesuits on mission in the Americas. The same can be observed in the production of other members of the Society of Jesus, such as Fathers Florián Paucke, Martín Dobrizhoffer and José Sánchez Labrador, who collected and systematized valuable knowledge about the fauna and flora of the American continent. More than the influence exercised by medical theories in force in Europe, the works written by these Jesuit missionaries, in the Americas or in exile, ${ }^{20}$ present evidence of the appropriation, diffusion and circulation of therapeutic procedures and the undeniable contribution of indigenous healing knowledge and practices. This is what we see in the works written by Father Sánchez Labrador, whose work Paraguay Natural is the subject of this article.

\section{From the Americas to exile: a Jesuit expelled in Ravenna}

José Sánchez Labrador was born in La Guardia, in the province of Toledo, on September 19, 1717 [or 1714], and died in Ravenna, on October 10, 1798. He joined the Society of Jesus on October 5, 1731, according to Ruiz Moreno, ${ }^{21}$ or on September 19, 1732, according to Sainz Ollero and colleagues ${ }^{22}$ and to Javier Baptista, ${ }^{23}$ having studied Grammar and Humanities.

19 The term "knowledge" is used from the understanding and affiliation to a cultural and global History of Science, which "studies circulation shaped by global exchange and intersecting cultural ties (crosscultural)." Rafael Gaune and Antonella Romano, "Fragmentos de un mundo en tránsito entre América y Europa. Experimentos desde Chile," Revista História Unisinos 23, no. 2 (2019): 138-43, on 141.

20 The exile began in 1767, when King Charles III of Spain expelled more than two thousand Jesuits from their domains, both Spain and Spanish America, who went mainly to Italy.

${ }^{21}$ Aníbal Ruiz Moreno, La Medicina en "el Paraguay Natural" (1771-1776) del P. José Sánchez Labrador S. J.: Exposición comentada del texto original (Tucumán: Universidad Nacional de Tucumán, 1948).

${ }^{22}$ Hector Sainz Ollero, Hélios Sainz Ollero, Francisco Suárez Cardona and Miguel Vázquez de Castro Ontañón, José Sánchez Labrador y los naturalistas jesuitas del Río de la Plata (Madrid: Mopu, 1989).

${ }^{23}$ Javier Baptista, "José Sánchez Labrador," in Diccionário Histórico de la Compañia de Jesús, eds. Charles O’Neill and Joaquín-María Dominguez, Vol. 4 (Rome: Institutum Historicum SI; Madrid: Universidad de Comillas, 2001), 3492-3. 
He began his studies in Philosophy at the Novitiate of San Luis de Sevilla, interrupting them to travel to the River Plate in 1733, accompanying Procurator Antonio Machoni. From 1734 to 1739 , he studied Philosophy and Theology at the University of Cordoba, completing his studies in the summer of 1739. According to his biographers, between the years 1741 and 1746 , he served as a teacher in the same city, studying, simultaneously, Natural History.

Thus, like many other Jesuit priests and brothers who preceded him in the American mission lands, Sánchez Labrador was not dedicated exclusively to the conversion of the indigenous people, but also to the study of the American fauna and flora that he observed in the different regions of the Jesuit Province of Paraguay ${ }^{24}$ where he served as a missionary. It is known that between 1747 and 1767, the Jesuit priest worked alongside the reductions of San Francisco Xavier, Santa Maria la Mayor, La Cruz, Santo Thomé and San José. From 1757, he began to work in Apóstoles (Holy Apostles or Apostles Saint Peter and Saint Pablo), having as companions the priests Lorenzo Ovando and Segismundo Asperger, the latter, recognized for his work as a doctor and apothecary. It is known that two years later he taught Theology at the Colégio de Asunción, ${ }^{25}$ and that in the following year (1760), he went on mission among the Mbayás and Guarani Indians, who would later form the Nuestra Señora de Belén reduction, and among the Guanas Indians, with whom he created the reduction of San Juan Nepomuceno.

On August 14, 1767, shortly after his return from a trip to the Chiquitos Indian missions, Sánchez Labrador was informed of the decree expelling the Jesuits from Spain and its colonies. About two thousand Jesuits were expelled from Spanish America and taken, in precarious conditions, to Corsica, from where they were mostly sent to the cities of Faenza, Ravenna, Brisighella and Imola. Sánchez Labrador settled in Ravenna, Italy, where he was Superior of one of the houses that the Society of Jesus owned in the city. He remained in this exile for thirty years, a time during which he devoted himself to writing his main works, Paraguay Católico (Catholic Paraguay), Paraguay Cultivado (Cultivated Paraguay) and Paraguay Natural Ilustrado (Illustrated Natural Paraguay), ${ }^{26}$ the latter being started in the Americas and concluded in Ravenna:

${ }^{24}$ Throughout the seventeenth and eighteenth centuries, the Jesuit Province of Paraguay had more extensive limits than those of the modern Paraguayan Republic, encompassing territories in Brazil, Paraguay, Uruguay, Argentina and Bolivia.

${ }^{25}$ Baptista, "José Sánchez Labrador," 3492.

${ }^{26}$ Paraguay Católico (Catholic Paraguay) was published in two volumes in 1910, and Sánchez Labrador highlighted in it the reports of the trips he made and his relationship with indigenous groups, without delving into the descriptions of nature. The descriptions and notes of botany, zoology, geology and agriculture were intended for Paraguay Cultivado (Cultivated Paraguay) and Paraguay Natural Ilustrado (Illustrated Natural Paraguay). 


\begin{abstract}
The date of edition of this set is approximately between 1771 and 76, when he was exiled in Italy. . . . the detail of his descriptions, together with certain citations found in the text referring to interruptions in writing derived from the problems that arose in daily coexistence with the Indians, indicate that Father Sánchez Labrador must have saved part of his original manuscripts, which allowed him to later reconstruct such detailed and prolific descriptions and stories. ${ }^{27}$
\end{abstract}

The original manuscripts of the work are found in the Archivo Romanum Societatis Iesu (ARSI) and have already deserved some studies, among which we highlight those by Furlong; ${ }^{28}$ by Aníbal Ruiz Moreno, La Medicina en “el Paraguay Natural” (1771-1776) del P. José Sánchez Labrador S. J.: Exposición comentada del texto original (Medicine in "Paraguay Natural" [17711776] by P. José Sánchez Labrador S.J.: Commented exposition of the original text), by Ollero, Cardona and Ontañon, José Sánchez Labrador y los naturalistas jesuitas del Río de la Plata (José Sánchez Labrador and the Jesuit naturalists of the River Plate), Asúa, Science in the Vanished Arcadia, Knowledge of nature in the Jesuit Missions, ${ }^{29}$ Asúa, Natural History in the Missions, and by Fleck, Artes de curar em um manuscrito jesuitico inédito do Setecentos. O Paraguay Natural Ilustrado do Padre José Sánchez Labrador (1771-1776) (The healing arts in an unpublished Jesuit manuscript of the eighteenth century. Paraguay Natural Ilustrado by Priest José Sánchez Labrador [1771-1776]). ${ }^{30}$ It is a consensus among historians that the Jesuit "carried out one of the most extensive works on the nature, geography and societies of the colonial River Plate region," 31 from which doubts and hypotheses arise as to how he wrote such a vast and detailed work, suggesting that, even though he was able to take some of the notes made in South America with him, most of the volumes in the work must have been written from the memories of his experiences as a missionary and as a naturalist in American lands. ${ }^{32}$

\footnotetext{
27 Sainz Ollero et al., José Sánchez Labrador, 211-2.

${ }_{28}$ Guillermo Furlong, Naturalistas Argentinos durante la dominación hispânica (Buenos Aires: Huarpes, 1948).

29 According to Asúa, Sánchez Labrador can be considered "one of the most enlightened of the Jesuits writers of Natural History," having his own way of organizing and presenting information in his Paraguay Natural Ilustrado, but maintaining the way of writing based on the Jesuitical education. "He organized methodically his subject matter and under each heading rehearsed in scholastic fashion the opinions of different authors, discussed the pros and cons of each of them and ended by expounding what he considered the sound opinion. This was the basic layout of the education which he and his fellow Jesuits had gone through." See: Asúa, Science in the Vanished Arcadia, 76.

${ }^{30}$ Eliane C. Fleck, As artes de curar em um manuscrito jesuitico inédito do Setecentos: um estudo do Paraguay Natural Ilustrado do padre José Sánchez Labrador (1771-1776) (São Leopoldo: Unisinos e Oikos, 2015).

31 Sainz Ollero et al., José Sánchez Labrador, 108. According to Del Valle, "The Jesuits fulfilled an important function in the search for information: they were the ones who were physically there, living with the indigenous people and in an environment full of novel natural objects and therefore waiting for their cataloging." See: Ivone Del Valle, Escribiendo desde las márgenes: colonialismo y jesuitas en el siglo XVIII (México: Siglo XXI, 2009), 52.

32 Sainz Ollero et al. did a tireless search for Sánchez Labrador's handwritten works in several archives and reported difficulties on identifying and locating these works. Based on their search, they state that "The initial surprise we found in this case is the practical certainty that Sánchez Labrador, in spite
} 
If, on the one hand, it can be said that "part of Sánchez Labrador's documents remained in the Americas," ${ }^{33}$ which is attested by the Jesuit, when stating that "for missing the papers and notes, which were intercepted in the city of Buenos Ayres," ${ }^{34}$ on the other hand, "it is the practical certainty that ... he was able, despite Bucareli's orders, to transfer part of his writings with him to his Italian exile," 35 due to certain "strange permissiveness" and the conditions in which the expulsion took place in Asunción, that "they were much more benign than in the rest of the cities of the River Plate" and, also, to the "somewhat special relationship between our author [Sánchez Labrador] and Bucareli." ${ }^{36}$ To support this hypothesis, the authors used a passage of the Report written by Sánchez Labrador himself, upon arriving at the Port of Santa Maria, in which the Jesuit missionary informs that he had made "a trip to discover the Missions of Chiquitos ... in the name of the King our Lord and the honorable Mr. Don Francisco Bucareli y Ursúa, Lieutenant General and Governor of Buenos Ayres asked him for an exact diary and map which he worked and delivered to the Honorable who offered to refer him to his Majesty." ${ }^{37}$

Throughout the four volumes of Paraguay Natural (Natural Paraguay), the Jesuit uses expressions such as por aca (over here), de aqui (from here), tenemos aqui (we have here) and other words that raise doubts in relation to the place where he wrote it. In the third Book of Volume II, for example, when describing the production of musical instruments by the Guarani and Mbayá Indians, he states that hoy dia (today) and ahora (now) remain producing in the same way, leading us to question also the period he was referring to. In this same book, he writes "The

of Bucareli's orders, managed to take with him part of his writings to the Italian exile." See: Sainz Ollero et al., José Sánchez Labrador, 106. The authors cannot determine how many writings Sánchez Labrador could take with him to the exile, neither explain surely on what circumstances he received this permission. Sainz Ollero et al. simply affirm that the withdrawal of the Jesuits from Asuncion was much quieter than in other cities of the Jesuitical Province of Paraguay. These authors also point to the existence of a possible relationship between Sánchez Labrador and Francisco Bucareli y Ursúa, Lieutenant General and Governor of Paraguay in this period. According to them, Bucareli was not in favor of the Society of Jesus but kept a cordial relationship with some Jesuits with the goal, probably, of benefitting from valuable information.

33 Sainz Ollero et al., José Sánchez Labrador, 106.

${ }^{34}$ Ibid., 358.

${ }^{35}$ According to Baptista, Sánchez Labrador, in spite of the prohibition, "could incomprehensibly take with him part of his writings to the exile." Baptista, "José Sánchez Labrador," 3492. However, Sainz Ollero et al. believe that it is still difficult to know whether Sánchez Labrador was able or not to travel to the exile with some of his notes, but they claim that it is certain that he had to write most of his works using mainly memories.

${ }^{36}$ Sainz Ollero et al., José Sánchez Labrador, 106.

${ }^{37}$ Ibid., 107. On this last trip made by the Jesuit in American territory, Furlong and Sainz Ollero et al. claim that Sánchez Labrador was the first to follow the path that would link the Guarani reductions to those of Chiquitos, in Bolivia, which would have resulted in a diary and a map that were handed over to Francisco Bucareli y Ursúa, governor of Buenos Aires at the time of the expulsion of the Society of Jesus. See: Sainz Ollero et al., José Sánchez Labrador, 107. 
cold regions of the south here in Paraguay produce their peculiar plants ..." and, at the end of the page, "In Paraguay, we don't need the Simaroba bark ..." [emphasis added]..$^{38}$ These passages seem to reinforce, to a great extent, both the hypotheses that maintain that the author started writing the work in American lands, and those that argue that the Jesuit took many of his notes with him, since Sánchez Labrador treats Paraguay as here and says he did not miss Simaroba, as if he was still in the Americas.

Also in the fifth Book of the Volume of Botany, we find the following statement by the author: "I am convinced that el Tachuache is a [species] of what we call here (aca) Cà̀ Cambi [emphasis added]." 39 The use of the word aca suggests that he was in Paraguay when he described this plant, as in this other passage in which he states: "I have considered them extremely important at the same time that they are feasible in these Provinces, which abound in the Materials and Ingredients to practice them" [emphasis added],${ }^{40}$ which leads us to deduce that he would be referring to the Jesuit Provinces of the Americas.

Although these passages support the possibility that Sánchez Labrador took with him part of the notes made during a period when he served as a missionary, in other parts, the Jesuit himself talks about Ravenna and brings information that also corroborates the hypothesis that the greater part of Paraguay Natural Ilustrado was actually written during exile. ${ }^{41}$ In a certain part of the third Book of Part Two, he makes reference to the city of Ravenna:42 "In the well-stocked and neat Apothecary, which in the ancient city of Revenna [sic] has the monastery of Religious

38 José Sánchez Labrador (1771-1776), Paraguay Natural Ilustrado. Noticias del pais, con la explicación de phenomenos physicos generales y particulares: usos útiles, que de sus producciones pueden hacer varias artes, Ravenna (Manuscript), Archivo Histórico de la Compañía de Jesús (ARSI), Roma (1772, Volume II, Book III), 260, hereafter cited as Sánchez Labrador, Paraguay Natural (ARSI).

39 Sánchez Labrador, Paraguay Natural (ARSI), 1772, Tome II, Book V, 335.

${ }^{40}$ Ibid., 462.

${ }^{41}$ Our analysis of Paraguay Natural Ilustrado leads us to believe that its Parts were the last to be written, because, along with them, Sánchez Labrador frequently mentions the other two works Paraguay Católico and Paraguay Cultivado, often highlighting in which Part, Book or Chapter the reader can find certain information. In the first book of the Volume of Botany, he writes: "If such mutations are to be admitted as true, or rejected as false, according to what we say in Paraguay Cultivado's Book III. Chapter V." Sánchez Labrador, Paraguay Natural (ARSI), 1772, Tome II, Book I, 92. Other evidence is found in book I of the first Volume, in which is indicated the reading of Paraguay Católico, which, incidentally, he does with some frequency: "The rest pertaining to the establishments of the Castilians in Paraguay could be read in the Paraguay Catholico" [emphasis added]. Sánchez Labrador, Paraguay Natural (ARSI), 1771, Tome I, Book I, 15.

${ }^{42}$ Ravenna, located near the Adriatic Sea, between the cities of Bologna and Rimini, was once the most important city in the Emilia Romagna region and the capital of the Western Roman Empire between 402 and $476 \mathrm{AD}$. The city has the Biblioteca Classense, one of the most important in Italy, dating from the seventeenth century. 
Benedictines, who they call San Vidal, the one who cared for her, a very intelligent man, taught some missionaries from Paraguay a resin bun, wondering if we knew her" [emphasis added]. ${ }^{43}$

In this passage, Sánchez Labrador not only makes it clear that he was in Ravenna, Italy, but reports that he had met the city's Benedictine monastery apothecary in the company of other priests who had also been missionaries in Paraguay, which points to a likely exchange of information among these individuals, contributing significantly to the writing of the three works of the Jesuit. This is also evidenced in another excerpt from Book III, in which the author informs he was in Bologna, probably accompanied by other exiled Jesuits: "In the beautiful Especula of the city of Bologna, they showed us the Herb of Paraguay among the vegetable productions, and rare of the Indies" [emphasis added]. ${ }^{44}$

In this same third Book, when explaining the Herb of Paraguay, Sánchez Labrador states that "in Italy with the arrival of the Jesuits, People of distinction have drunk it with the same good success, in all these lands they know Sumac well, and they do not even think of it as Herb of Paraguay" [emphasis added]. ${ }^{45} \mathrm{He}$ also reports the use, in Ravenna, of the spines of a plant known as Zamuî: "In the city of Ravenna, this remedy had a good effect on many people, to whose eyes it was applied in the years 1770 and 1771 " [emphasis added]. ${ }^{46}$

Also in the fifth Book, the author makes references to Ravenna, which seems to prove even more that most of the work was, in fact, written during the exile, and in this passage he compares the Italian city with Peru and Paraguay: "In this city of Ravenna we have seen Gardens, and Orchards of these plants, and they did not differ at all from those of Peru, and Paraguay" [emphasis added]. ${ }^{47}$ In Book Six of Volume II, we find a passage in which Sánchez Labrador reports that he passed on information to another Jesuit who was in Ravenna, which shows both the exchange of information between members of the Society who had been expelled, and that the work was written during exile: "Later I referred this news to Priest Diego Moreno, from the Province of Chile, who was at that time in Ravenna, a serious fellow, and one of great discernment" [emphasis added]. ${ }^{48}$

There is another point, commented on by Moreno and Sainz et al., which proves that the Parte Segunda of Paraguay Natural Ilustrado was completed in Ravenna, Italy. This volume is characterized by the large number of references to authors recognized in Europe and to

\footnotetext{
43 Sánchez Labrador, Paraguay Natural (ARSI), 1772, Tome II, Book III, 145.

${ }^{44}$ Ibid., 221.

45 Ibid., 221.

46 Ibid., 252.

47 Ibid., Book V, 336.

${ }^{48}$ Ibid., Book VI, 369.
} 
works on Natural History. ${ }^{49}$ Among the works most cited by him is the Diccionario razonado universal de historia natural (Reasoned universal dictionary of natural history), written by Jacques Christophe Valmont de Bomare-whom Sánchez Labrador calls Señor Bomare-, which began to be published in 1764. Taking into account that Sánchez Labrador acted in the distant reduction of Nossa Señora de Belén, among the Mbayás Indians, when this book was published, and that, between 1766 and 1767 , he was on his exploratory trip to the territory of the Chiquitos indigenous people, there is no possibility that he had access to the Bomare's dictionary in the Americas.

Despite all these considerations, which lead us to believe that most of the Paraguay Natural Ilustrado was written in Europe, there is not enough evidence to confirm both the hypothesis that the author managed to take some notes from South America with him, as well as the one that argues that he was not allowed to do so. The assumptions raised and the arguments presented by Sainz et al. to explain the detail and extent of the work seem to prove the impossibility of Sánchez Labrador having done it exclusively from memory, as the detailed drawings and descriptions of Part Two and Part Four seem to suggest.

Scholars of Sánchez Labrador's works, however, emphasize that his production falls under the category of exile writing, a "particular genre" of Jesuit writing, ${ }^{50}$ which did not intend only to "show and spread the grievances during their extradition and their consequences in Europe," but also to "reaffirm the identity of the Jesuits" ${ }^{\text {"1 }}$ and to disseminate the knowledge produced by the Society of Jesus on and in Platin America, in particular, on Natural History and Medical Botany. ${ }^{52}$ In this sense, it is worth mentioning the countless evidences of the circulation of

49 Asúa states that Sánchez Labrador's works are an ambitious encyclopedia. He intended "some kind of dialogue with the Moderns, with whose works he became acquainted through his readings, especially encyclopedias of Natural History and medical dictionaries." See: Asúa, Science in the Vanished Arcadia, 89. Among the referred authors, we highlight Robert James (1703-1773), Nicolás Lemery (1645-1715), Esteban Geoffroy (1672-1731), Jacques-Cristophe Valmont de Bomare (1731-1807), Martial (AD 38/40-?), Pedanius Dioscorides (AD 40-90), Athanasius Kircher (1601-1680), Martin Lister (16381712), Johann Schröder (1600-1664) and Claudius Galenus (AD 129-199/217).

50 Asúa distinguished three genre groups of these Jesuits' natural histories, based on criteria such as scope, language, authorial voice and chronology, which were: the chronicles, the memories and the encyclopedias. According to this author, Sánchez Labrador's Paraguay Natural Ilustrado fits in the third group and has the ambitious task of being the encyclopedia of Paraguay with most of its books containing a summary of encyclopedic material. See: Asúa, Science in the Vanished Arcadia, 70.

51 Maria Cristina Torales Pacheco, "Diversidad, unidad e identidades en la Provincia Mexicana de la Compañía de Jesús" in Escritura, imaginación politica y la Compañía de Jesús en la América Latina [siglos XVI-XVIII], eds. Alexandre Coello de la Rosa and Teodoro Hampe Martínez, 167-83 (Barcelona: Ediciones Bellaterra, 2011), 179.

52 In the eighteenth century, the Jesuits abandoned "the arguments of the marvelous nature, full of portents and signs ... to initiate the formulation of an enlightened thought and create their own ethnographic and scientific notions of the American world" and this change in perception of the natural world was constituted as "means through which the expelled Jesuits emphasize their intellectual control and possession" from the regions where they worked and from the indigenous populations who they 
libros de medicina (medical books) and the dialogue that Sánchez Labrador maintained with other members of the Society of Jesus, as in this passage in which he describes the native plant Caaboroy from the record that Jesuit brother Pedro Montenegro made at Materia Médica Misionera (Missionary Materia Médica), ${ }^{53}$ still in the first decade of the eighteenth century:

this is how they call a plant, which abounds in Paraguay itself, which the Spaniards name, field Basil or wild Basil. It resembles in everything the Garden Basil, to which the Guarani Indians give the same name. The field Basil, when fresh, gives off a very mild clove-like smell. Brother Pedro Montenegro, Jesuit, and distinguished Botanist, took it like Tea, and said that it beautifully comforted the stomach [emphasis added]..$^{54}$

Or, in this one, in which, when talking about a kind of tea, he makes reference to another Jesuit missionary who worked in Argentine Patagonia:

The leaves of this little tree are very fragrant; and in Chile, and in Paraguay, they use them, like Tea, with the same or better effects. For a kind of true Tea this plant was qualified by P. Thomas Falconer, English, Jesuit in the Province of Paraguay, a very intelligent fellow on Botany and Medicine. The Authority alone of this distinguished Missionary placed the Culén in a higher degree of esteem than it previously had. ${ }^{55}$

The circulation of information about curative practices and knowledge between the Society's reductions in the region covered by the Jesuit Province of Paraguay can also be seen in the mention made by the Jesuit to a "Reduction of Chaco Neophytes [where] an epidemic was stopped with the so-called remedy from tobacco, as it was referred to me by Priest Luis Olcina, who was currently in it, and other missionaries" [emphasis added]. ${ }^{56}$

But the dialogue that the missionary established with other Jesuits was not restricted exclusively to the period when priests and brothers, as expatriates, worked in the American territory, as can be seen from this passage, in which Sánchez Labrador, already installed in Ravenna, refers to having received news from:

Priest Diego Moreno, from the Province of Chile, who was at that time in Ravenna, a serious fellow, and one of great discernment. He told me that in Massa Lombarela, where he lived, near the city of Inmola, there was a Knight Count of the first nobility, very curious, and who delighted in Botany and Gardening, who in his beautiful Garden also had the Payco, name he gave for tea, and as such he used. I begged the Father, upon his return, to inform himself promptly of this matter, and

converted or met as missionaries." Figueroa and Ledezma, El saber de los jesuitas, 22.

53 Pedro Montenegro, Materia Médica Misionera (Buenos Aires: Edición de la Biblioteca Nacional de Buenos Aires, 1945).

${ }^{44}$ Sánchez Labrador, Paraguay Natural (ARSI), 1772, Tome II, Book VI, 448.

55 Ibid., 365-6.

56 Ibid., Book VI, 434. 
write me about what he found out. He did so and answered what I am going to write with his formal words [emphasis added]. ${ }^{57}$

As can be seen, the circulation of information that characterized the Society of Jesus performance in the areas in which it operated, forming an efficient network that united the Americas to Europe, ${ }^{58}$ was not limited to the period in which Sánchez Labrador lived as a missionary. During his exile in Ravenna, the Spanish Jesuit not only moved to nearby cities, but also maintained correspondence with other exiles, which made it possible to resolve doubts, and rectify or confirm his observations or memories of the experiences he had lived. ${ }^{59}$

\section{On the virtues and toxic properties of some native American plants}

The work is composed of four Parts or Volumes, with the Parte Primera (First Tome) having the Books: I. Diversidad de Tierras, y Cuerpos terrestres (Land Diversity, and Terrestrial Bodies); II. Agua, y varias cosas a ella pertenecientes (Water, and various things belonging to it); III. Ayre, Vientos, Estaciones del Año, Clima de estos Países, y Enfermedades más ordinárias (Air, Winds, Seasons of the Year, Climate of these Countries, and more ordinary Illnesses); the Parte Segunda, the Books: I. Botanica, o de las Plantas en general (Botanic, or of Plants in General); II. Selvas, Campos, y Pradarias del Paraguay (Jungles, Fields, and Grasslands of Paraguay); III. Los Árboles en particular (Trees in particular); IV. Palmas, Tunas, y Cañas (Palms, Tunas, and Reeds); V. Ycipos, y otras Plantas Sarmentosas (Ycipos, and other Sarmentose Plants); VI. Algunos Arbolillos, Matorrales, y Hierbas (Some Shrubs, Bushes, and Grasses); VII. Algunos útiles, y curiosos usos (Some useful, and curious, uses), written in 1772; the Parte Tercera has the Books: I. Animales Quadrupedos (Quadruped animals); II. Las Aves (The Birds); III. Los Peces (The Fish), made in 1771, and Parte Quarta, the Books: I. De los Animales Amphybios (Of the Amphybian Animals); II. De los Animales Reptiles (Of Reptile Animals); III. De los Insectos (Of the Insects), which were completed in 1776

\footnotetext{
57 Ibid., 369.

58 The Society of Jesus must be understood as an "order whose characteristic was to train priests with outstanding intellectual capacities, theologians, philosophers and even natural, mathematical and physical philosophers who debated with the illustrious men of the so-called scientific revolution in Western Europe." María Soledade Justo, "Paraguay y los debates jesuíticos sobre la inferioridad de la naturaleza americana," in Saberes de la conversión. Jesuitas, indígenas e Imperios coloniales en las fronteras de la Cristiandad, ed. Guillermo Wilde, 155-74 (Buenos Aires: Editorial Sb, 2011), 156. It is necessary, however, to bear in mind that, throughout the eighteenth century, "the writings and investigations of the Jesuits continued to supply valuable information without necessarily being recognized, as an order, ... in terms of equality by scientists." See: Del Valle, Escribiendo desde las márgenes, 49.

${ }^{59}$ According to Sainz Ollero et al the expulsion had a positive impact on their scientific background, and the contact with European science "of the moment and the classical authors constitutes a fundamental aspect of their work, which stands out for their erudition and encyclopedism." See: Sainz Ollero et al, José Sánchez Labrador, 204.
} 
The work has 127 drawings made by the author himself. In Volume II we find 105 images, in Volume III, 13 images, and in Volume IV, 9 images. Volume I is the only one without illustrations. ${ }^{60}$ In rarer situations, the Jesuit inserts some drawings in the middle of the written pages, sometimes at the beginning of the pages or, even, in the middle of the text. Unlike the 127 already mentioned drawings, these other drawings did not serve to illustrate the plants, animals, practices or elements that Sánchez Labrador wrote about, but rather to contribute with some additional explanation by the author. For this reason, these drawings usually have a name and a sort of key explaining what it is about. An example of this can be found in the seventh book of Volume II, where Sánchez Labrador, when talking about varnishes, inserts a drawing of a Quadrangle in which the wooden sheets, or canvases, were placed to have their two surfaces varnished. ${ }^{61}$

Next, we will highlight the virtues and toxic properties of some of the native American plants presented in the Second Volume, with more than 500 pages distributed in seven books, consisting of seventy-six chapters, which address physiology, anatomy, histology, plant reproduction, forests, fields, swamps, deserts, pharmacology, cultivation and ethnobotany. In the introduction to this volume, Sánchez Labrador refers to the division between a practical and a speculative botany proposed by some scholars and mentions: "some principles concerning the cultivation, and work of the Plants, although this will be set aside, reserved for another work, whose First Tome has already been written, with the purpose of such an important matter, entitled Paraguay Cultivado." 62

The analysis carried out revealed that Labrador made use of both his own observationsfrom expeditions he carried out in the River Plate region—and information he obtained from indigenous people, as well as from classical authors and authors contemporary to the work, many of it written by other Jesuit naturalists, with whom he established an interesting dialogue. In one of the mentions to the rhubarb, Sánchez Labrador made this quite evident: "He told me that he had been introduced to them by a Missionary Father, knowledgeable about plants, and although he mispronounced it, as is usual with foreign names, I could understand that he meant Rhubarb." ${ }^{3}$

${ }^{60}$ The drawings are usually placed on sheets separated from the text, and they contain the page numbers of the work to which they refer. In Volume II, the images appear inserted in the middle of the written pages, constituting representations of the plants being mentioned in the text. In Volume III, the images drawn show up at the end of each of the three books that compose it, while in Volume IV the images appear at the end of the three books. In the case of these last two volumes, the images are not numbered, and it is not possible to state which book, chapter or page each one refers to.

${ }^{61}$ Sánchez Labrador, Paraguay Natural (ARSI), 1772, Tome II, Book VII, 472.

${ }^{62}$ Ibid. Introduction, f. num. I.

${ }^{63}$ Ibid., Tome II, Book VI, 408. 
In Paraguay Natural, each plant described by Labrador is preceded by morphological and ecological descriptions, followed by information about its usefulness, in addition to the method of obtaining and cultivating. The work includes classification criteria specific to botany, such as taxonomy, morphology, anatomy and, also, ethnobotanical aspects related to cultivation, which, according to the Jesuit priest, were, until that moment, treated in isolation by other scientists. ${ }^{64}$ This is evident in the statement made by Sánchez Labrador at the opening of the Botany Volume:

Many authors restrict Botany only to the knowledge of the Classes, Genera, and Species of Plants, its exterior form, and the description of all its parts. I agree that its object includes the entire Kingdom of vegetables, in all its states, in all its uses, and in all its respects [emphasis added]. ${ }^{65}$

In it, the author adds that he intended to make a complete and detailed description about the plants of the regions of Platin America, especially of the Jesuit Province of Paraguay, which is evidenced in this passage: "if the reader looks closely, will see that it is not a question here of giving a fast and lean news of the plants of Paraguay, but of, as well as possible, formulating a Botany, composed of the plants that grow in this country, which have been considered so far with almost no care and determination" [emphasis added]. ${ }^{66}$

In this Tome, the chemical knowledge of Sánchez Labrador is also evident, especially in the section dealing with the colors of the plants and the procedures that should be adopted, still during planting, to obtain certain colors. The author talks, quite appropriately, about the influence of acids and alkalis in the colors of flowers, informing that the acids would lead to

${ }^{64}$ The pre-Linnaean naturalists exerted great influence on the Jesuit naturalists, who observed a script that foresees, for the study of animals and plants, "the name and its linguistic origin, form, appearance and qualities, distribution area, behavior, collection or capture systems, customs, uses ..." See: Sainz Ollero et al., José Sánchez Labrador, 173-5. However, in the first hundred pages of the Volume of Botany, which consist of a general introduction to Botany, Sánchez Labrador reveals not only to know the works of the Swedish botanist Carl Linné, but also positions himself in relation to the Linnaean methodology and classification, reaffirming his option for the grouping by biological forms proposed by Joseph Pitton de Tournefort. See: Sainz Ollero et al., José Sánchez Labrador, 177-209. It is plausible, however, to assume that Sánchez Labrador opted for the pre-Linnaean system due to insufficient morphological data on certain South American species and families.

${ }^{65}$ Sánchez Labrador, Paraguay Natural (ARSI), 1772, Introduction, f. num. I. Despite having adopted "a prudent posture, managing a great scholarly apparatus, but without clearly defending any opinion" Sánchez Labrador partially applied the proposed Linnaean system in the "grouping of palm trees, very important in the local flora and to which a great deal of attention is paid, with the reeds, grasses adapted to periodically flooded environments, both belonging to the large group e monocotyledons." See: Sainz Ollero et al., José Sánchez Labrador, 179-213. The authors also inform that, in the midst of the scientific Renaissance, in Spain, unlike Italy and other European countries, there was "a certain 'Linnaeophobia' ... headed by the Catalan, José Quer, director of the recently created Botanical Garden of Madrid, due to certain derogatory comments that the Swedish naturalist had made about the Spanish botanicals." See: Sainz Ollero et al., José Sánchez Labrador, 175.

${ }^{66}$ Sánchez Labrador, Paraguay Natural (ARSI), 1772, Introduction, f. num. I. 
reddish tones, while the alkalis would cause greener tones. His explanations of the appearance of plants and the composition of soils, the differences between alkalis and acids, as well as volatile alkalis and volatile acids, and how these elements influence the color of plants, are quite complex and demonstrate significant knowledge, undoubtedly due to the contact with reference works on the theme. In addition to the morphological and ecological descriptions and information about their usefulness, and its methods of obtaining and cultivating, the Jesuit also presents a series of warnings, aiming to succeed in the search and use of a certain plant.

In the Introduction of Tome I, the Jesuit had already emphasized that "In the Treatise of the Plants the qualities of those fruits that abound in these Countries are listed. In the Treatise of Birds and Animals, we can see those that supply the best food." ${ }^{67}$ In this same Tome, we find a subchapter entitled Frutas buenas y modo de usarlas (Good fruits and how to use them), in which he highlights its diversity, as well as the care in relation to its consumption:

\begin{abstract}
The rich fruits that this country produces can be taken, and eaten with good effects. Peaches of all kinds, apples, lemons, citrons, Chinese Oranges, Pomegranates, Quinces, Mbarucuyas, or Granadillas, and other similar ones. The pineapples, or Ananas in moderation, watermelons, melons. ... Because all these things greatly help the liver, provided they are seasoned, or perfectly ripe. Bananas, taken with discretion, are healthy: and also the juice from sweet canes, which refreshes the blood and strengthens the stomach. As for these fruits, it is necessary to take care, in addition to their full seasoning, to pick them when the sun has already exhaled from them the nocturnal vapors Also, with the exception of the astringent ones, it is better to eat them before other foods, and not after them. Because having a lot of light substances they are easily corrupted, and they mainly harm those with a troubled, and weak stomach. ${ }^{68}$
\end{abstract}

Sánchez Labrador, however, makes sure to mention the risks that people would be taking if they consumed certain plants without knowledge about their properties, or in therapeutic procedures considered harmful to health. The measures of care that should be taken are discussed at the end of Book III of Tome II, in the topics titled Curiosidades (Curiosities), divided into two topics: Conocer las frutas saludables, o danosas (Knowing the healthy or unhealthy fruits) and No perder el rumbo, o camino en los bosques (Not to lose track, the path in the forest). In the first, Sánchez Labrador warns future missionaries and those who would go deep into the woods in search of the native nonbelievers to stay attentive to the existence of poisonous and edible fruits. The Jesuit priest recommends that only the fruits that served as food for insects and birds should be consumed, as these, certainly, should not be poisonous. Despite recognizing that this knowledge came from observation and experience, Sánchez Labrador informs that such information was in the work of the botanist Francisco Eulalio Savastano, whom he refers to as the "elegant Poet." According to Sánchez Labrador, "the Europeans, who had no knowledge of

\footnotetext{
${ }^{67}$ Ibid., Tome I, Introduction, f. I-II.
}

${ }^{68}$ Ibid., Book III, 532. 
plants and traveled at first through the jungles of the Americas, used this same clue to eat and consider as healthy those fruits that the birds ate as healthy." ${ }^{39}$

In Book III of Tome II, once more mentions are found to measures of care that should be taken when utilizing, for example, certain "Pine nuts [which] purge even more violently than the common Castor bean, or Tartago; and it is a dangerous purge, even if accompanied by some corrective." According to Sánchez Labrador, "Three, or four Pine nuts, eaten raw . . a are capable of causing nausea and vomiting, and of putting someone on the threshold of death [because] they cause fatal fainting, and it is necessary to respond promptly with Alexipharmacos [antidotes]." Later, he informs that he spoke "from his own experience; because a Healer had given me this purge ... in nineteen fierce evacuations, he gave me others, many times at the risk of losing my life with extreme fainting. Thank God that a Knight, my Friend, knows the Purgative and helped me in time," which seems to justify the recommendation he makes in the topic "Legitimate use of this purge":

Its legitimate use, and not so risky, is in the daytime obstructions of the entrails. They take four, or five, very mature Pine nuts, cleaning them from the outer and inner coating; then, they are lightly toasted; they are infused in a little wine with a corrective, and thus administered. Two things should be noted: first, it consists of experience in Paraguay that, if the Pine nuts were macerated in wine, and the operation exceeds what should be done, it is stopped by drinking water, or a good broth. The opposite happens if they were given in water, or broth: the remedy is wine. Second, that some are falsely persuaded that the Pine nuts take away all their malignancy and fury by removing the coating, splitting it in half. Because after all this, if it is exceeded, they act with all efficiency. Experience it, and Pison answers it. ${ }^{70}$

In this same Book, the Jesuit priest describes a tree, that due to its toxicity, had caused infirmities and even the death of many of the first Spanish conquerors:

The wood of this tree is beautiful, hard, and solid like that of Walnut.... When the bark of the manchineel tree is cut a few times, it sprouts a juice as white as milk, which is a pungent, very active, burning, and deadly poison. Whoever risks resting in its shade, soon knows the malignancy: the eyes become inflamed, and the whole body swells. If the dew and the rain, which falls on its leaves, touch anyone, they raise blisters on the skin; so does the leaf. . . . In short, this tree contains in all its parts a corrosive and horrible [toxic], like the oboxoos. ${ }^{71}$

According to Sánchez Labrador, the Caribe natives, "when they are going to poison their arrows in the juice of this tree, they turn their faces, and cut the bark so that the juice does not splash them, especially in the eyes ...," adding that "The weapons, and Arrows that have been

${ }^{69}$ Ibid., Book I, 123-4.

${ }^{70}$ Sánchez Labrador, Paraguay Natural (ARSI), 1772, Tome II, Book III, 184.

71 Ibid., 244. 
anointed with the juice of the Manchineel Tree retain, for a long time, their poisonous quality, and this is observed in the arrows of the Chiquitos." ${ }^{\prime 2}$ On a specific topic, the Jesuit missionary describes the "Fatal Tree to the conquerors":

This is that tree so fatal to the Spaniards of the first conquest America, which cost many unwary men's lives who did not know it. Attracted by the beauty of its fruits, they ate them, swelled up, and died. The only remedy that experience had taught them at that time to prevent these deadly accidents was to drink the common olive Oil, a very effective antidote against the poison. They knew that repeated frictions and fresh drinks prevented the consequences of the poison. Some claim that one can be healed by drinking a glass of sea water promptly and fast. Perhaps salt and salt water would have the same effect. It has been observed that even the irrational animals, guided by their natural instinct, flee from this fatal tree, enemy of the living. To take advantage of its veined wood, they let it dry, and in this way they work it. ${ }^{73}$

If in Volume I Sánchez Labrador tells about the variety of fruits native to Paraguay, which, according to him, were very tasty, helped to maintain health and should be eaten preferably in the morning and before meals, in Book I of Volume II, Sánchez Labrador informs that it was "a delight to walk through the jungles of Paraguay," because "they recreate the smell, despite the fatigue of almost the whole body, the fragrant effluvia" released by the balms that sprouted from the trees. According to the Jesuit priest, "The Balm is nothing other than a resinous liquor, whose odor pleasant to man ... serves to restore health." 74 For the "Ancient physicians," the balms were "all kinds of medicine, distinguished by its pleasant fragrance," used against "putrefaction [and] corruption, cleaning, nurturing and healing wounds," being their first usage "to embalm, and preserve the dead bodies of those who had distinguished themselves with heroic and kind deeds to people with the practice of their virtues." 75 With the proof of its effectiveness for "the incorruption, which the Balms delivered to the corpses for many years, the intelligent began to believe that the effectiveness of the Balms could also benefit the living, prolonging their lives. ${ }^{.76}$

Among the plants presented, there is the Cupay (Copaifera sp.), vernacular name attributed to several native species producing therapeutic essential oils that were used in the Jesuit reductions in the preparation of several balms, useful in the treatment of both external lesions and smallpox. According to the Jesuit, a powerful balm was extracted from this plant, known as Cupay oil, Copayba balm (Copaiba balm) or Palo oil. The medicinal virtues of this plant include comforting the stomach (taking three to four drops in the morning), be diuretic, cure

\footnotetext{
72 Ibid.

73 Ibid.

${ }^{74}$ Ibid., Tome II, Book II, 107.

${ }^{75}$ Ibid., 107.

${ }^{76}$ Ibid.
} 
difficulties related to bad breath, induce labor, when applied to the vulva, and lessen the pain of those born with cold and wet temperaments. In addition to these applications, copaiba balm would also be well known for its effects on the healing of wounds of all types (except those produced by burns). It would also serve to contain blood flows resulting from the rupture of some vein or blood vessel, and it could be applied in cases of gangrene, gonorrhea or other illnesses that cause blood loss, because "It causes urine, quenches its burning, and cleanses the bloody, dirty, and rotten things of the belly that stop it."

When highlighting the virtues and applications of the balm extracted from Copaíba, Sánchez Labrador underlines that "has healed some sick people with no life expectancy," as in the cases of "poisonous animal bites": ${ }^{78}$

Indeed, in addition to what has been said, and what will be said, various experiences, repeated many times, and always successful, in patients who are almost dying, have made it known that, by taking it internally, it fortifies the heart, stomach, chest, head, brain; purifies the blood, expels from above, or from below, or by perspiration all bad humors; it excites the appetite, increases the natural heat in old people, and causes some sweat... When applied externally, it strengthens the nerves; resolves cold humors, heals wounds and burns; poisonous animal bites; rheumatism; stops gangrene; heals certain malignant stains. ${ }^{79}$

The Jesuit details, also, the location and the medicinal virtues of Aguape miri, which operated as "a cure as if by miracle": 80

it grows on the banks of streams, and in humid places. The leaf is round, placed on its long petiole; and it seems, or is what the Spaniards of Peru call Oreja de Abad [Abbot's Ear]. On the palate it is tasty, but it is much more useful to the eyes. Chewed, or crushed, and applied to the eyes sometimes in several nights, it overcomes all disease of them, undoes the cloudy visions, appeases the pain, restores to its normal the organ of sight, which heals as if by a miracle.... The

\footnotetext{
77 Ibid., Tome II, Book II, 139.

${ }^{78}$ It is interesting to note that in the Jesuit documentation there are frequent references to accidents involving poisonous animals, such as snakes, scorpions and spiders, which can be attributed both to the natural environment in which the reductions were established and to climatic disorders, such as droughts or floods, which may have favored their proliferation or displacement to other regions. Among the plants that both brother Montenegro (in his Materia Médica Misionera, 1710) and Father Sánchez Labrador refer to for specific use in accidents with venomous animals, is the "taropé," popularly known as figueirilha, of the Dorstenia brasiliensis Lam. Species, and which, in current works, is referred to for its anti-phallic, diaphoretic and anti-fever properties.

79 Sánchez Labrador, Paraguay Natural (ARSI), 1772, Tome II, Book III, 136.

${ }^{80}$ It must be kept in mind that, in the eighteenth century, doctors [and missionaries engaged in the care of indigenous diseases] did not yet have very rigorous terminology and safe methods of diagnosis at their disposal. There were also some illnesses that succumbed or seemed to succumb, leading the missionaries to establish a relationship between healing and miracles. On this theme, it is recommended to see more in Eliane Fleck, Entre a caridade e a ciência: a prática missionária e cientifica da Companhia de Jesus (América platina, séculos XVII e XVIII) (São Leopoldo: Unisinos; Oikos, 2014).
} 
Inca Garcilaso says wonderful things about this plant, which he calls Oreja de Abad, in relation to healing the eyes. ${ }^{81}$

In this same Book of Tome II, Sánchez Labrador admits that "the Indians, whose forces are unable to pay for the medicines, brought from afar, or the doctors, who still serve very little the wealthy ones of the Country, possess the knowledge of quite a few herbs, and plants, which they use successfully." 82 When referring to Acangita Plateada — and to Carquexa-the Jesuit, however, observes that "They do not know how to explain the causes that afflict the bodies, but with a medical instinct, to explain to me, the plants are not hidden from them, with which they are cured in a short time, without purging with violence, without causing bitterness in the mouth and thus eating all the entrails." In the reference he makes to the Palo Santo or Guayaco, the Jesuit mentions that the natives utilized it in different forms:

The Indians use the decoction of Palo Santo for stomach pains, born from [cold]. By boiling the splinters, abundant resin is extracted. From which, and from that the trees sweat, the unfaithful Mbaya Indians make use of to give a lustrous black varnish to the mouths of the water pots, in which they have water, and other utensils. It does not impart a bad taste to the water; because although it is bitter, it partakes of some sweetness, like that of the licorice; and when it hardens, it does not dissolve in the water, nor is its bitterness perceptible. The woodworm of the Palo Santo, placed on the sores, even if they are aged, cleans, and heals them. ${ }^{83}$

In the reference he makes to the tincture extracted from the Nandipa tree, Sánchez Labrador informs that "When the Indians are asked why they dye themselves with the Juice of the Nandipa, they answer that with this tincture they feel relief and rest for their bodies. The answer seems barbaric, but if it is well considered, it has a background of good physics" [emphasis added].$^{84}$ According to him, its use is justified:

The Indians tire themselves in their hunts, and in other exercises of their fickleness; the ardors of the sun make their bodies unmanicured, by the excessive perspiration. It is not a miracle, then, that they receive strength with this dye, which with its astringent virtue tightens the pores; it stops the copious perspiration, which was unbearable to them; and thus they are more agile, and fast. ${ }^{85}$

In Book VI of Volume II, we find a passage in which the Jesuit priest says that: "Tobacco kills snakes, and vipers, geckos, scorpions, and similar animals: and if they pierce a skin, a small

\footnotetext{
${ }^{81}$ Sánchez Labrador, Paraguay Natural (ARSI), 1772, Tome II, Book V, 355.

${ }^{82}$ Ibid., 131. On this subject, it is recommended to see more in Eliane Fleck, Mariana Joaquim, Maico Biehl, "En orden a sus virtudes y facultades medicinales: um estudo sobre o Paraguay Natural Ilustrado de José Sánchez Labrador SJ," Corpus. Archivos virtuales de la alteridad americana 6, no. 2 (2016): 1-43.

${ }^{83}$ Sánchez Labrador, Paraguay Natural (ARSI), 1772, Tome II, Book III, 189.

${ }^{84}$ Ibid., 262.

${ }^{85}$ Ibid.
} 
piece of Tobacco is inserted into the hole; or also if they receive the smoke, they die." 86 When talking about the death of animals, the Jesuit refers to "the Putrefaction of animal humors," stating that it was "truly [a] bowel movement [that] never produces acids, or flammable spirits, but phosphoric ones; and therefore completely different from all fermentation; because if it does not produce spirit, or burning, or acid, I will never call it fermentation." ${ }^{87}$

In continuity, Sánchez Labrador mentions that tobacco could be utilized as "a very effective remedy against Measles," warning, however, to "not apply any remedy; it is only good to take emetics, every day one of them, compounded with Tobacco: with these emetics, the headache and chest pain are removed." He adds that, during an epidemic "of measles in the Neophyte Guarani Mission," Priest Francisco de Azevedo would have used this preparation successfully, "that being six hundred sick people in the Ytapua Doctrine, and thirty, and eight; only twentythree died, and of these the most by their disorders." The same thing would have occurred "in a Reduction of Chaco Neophytes," where "an epidemic" was fought "with the remedy of the Tobacco." 88

It was the high populational densities, in the opinion of historians and demographers, that made the reductions very vulnerable to the epidemics of contagious diseases such as measles and smallpox, constantly referred to by the Jesuit missionaries both in the Annual Letters and in works like the one analyzed in this article. In the Letter-Report of 1747, Priest José Cardiel recommended missionaries coming to the Americas to bring some books, including one of home medicine, ${ }^{89}$ which could explain the knowledge and use of tobacco-based preparations by missionaries who were not versed in pharmacy or medicine. There is the possibility that the priests in charge of the reductions, mentioned by Sánchez Labrador, may have made contact with prescriptions or Medical Matters, which, after being copied by the authors themselves, or by indigenous copyists, circulated in the various regions served by the Society of Jesus, forming a network for the exchange of experiences and information, as evidenced in the passage transcribed from Paraguay Natural.

There are several passages in which the Jesuit gives emphasis to the medicinal virtues of American flora and describes its handling by the natives. In one of them he refers to the Ycica tree and to its resin, affirming that it can be found in the missions of the Chiquitos natives, who prepare it in the following way: "For this, the Indians put in hot water, sit the Resin, whose oil partly floats: they drink the water, and without further remedy they get rid of some stomach

${ }^{86}$ Sánchez Labrador, Paraguay Natural (ARSI), 1772, Tome II, Book VI, 434.

${ }^{87}$ Ibid., Introduction, f. num. X.

${ }^{88}$ Ibid., Book V, 434.

${ }^{89}$ Guillermo Furlong, José Cardiel SJ y su Carta Relación (1747) (Buenos Aires: Librería del Plata, 1953), 212-3. 
and belly afflictions caused by the cold." ${ }^{\prime 0}$ On that same page, the author reports that, already installed in Ravenna, he found Ycica's resin in an Apothecary, adding that: "In Paraguay itself, Ycica is so abundant that with it all the Apothecaries of Spain could be supplied." ${ }^{\prime 1}$

Healing knowledge and practices associated with plants, insects and bezoar stones ${ }^{92}$ didn't draw the attention of only Sánchez Labrador. Priests and brothers from the Society of Jesus, since the seventeenth century, produced treaties and prescriptions in which the incorporation of native elements to the medical theories and pharmacy practiced in Europe is evidenced. ${ }^{93}$ However, it is necessary to consider that such an approximation between the two continentsAmerican and European - took place "under the selective focus of the missionaries, because they understand the understandable and omit the residues of 'barbarism' and 'idolatry'." close association between scientific production and missionary activity can also be noticed in this affirmation made by Sánchez Labrador:

The Plant in its first being is all the work of the Divine Hand. The same God with sovereign rule on the third day of the World commanded the Earth that its bosom should produce the green grass, to produce its own seed; and also trees, that were laden with fruits according to their species, and the seeds, from which in the future each one would be born, and multiply perpetually. ... God made them all in this beginning of the World. . . . Indeed now, according to the laws, which at the beginning of things established their Auctor, seeds and Plants are born by true and natural production, to which the earth, the sun, and a proportionate mood concur as second causes. ${ }^{95}$

\footnotetext{
90 Sánchez Labrador, Paraguay Natural (ARSI), 1772, Tome II, Book III, 145.

${ }^{91}$ Ibid., 145.

92 On the highlight given by Sánchez Labrador to the medicinal virtues of plants, insects and bezoar stones, it is recommended to see more in Eliane Fleck, As artes de curar em um manuscrito jesuitico inédito do Setecentos: um estudo do Paraguay Natural Ilustrado do padre José Sánchez Labrador (1771-1776) (São Leopoldo: Unisinos; Oikos, 2015).

${ }^{93}$ But, if the incorporation of indigenous languages, therapeutic practices, knowledge and worldviews by the Jesuits conferred, as stated by Asúa, one of the "distinctive characteristics of science in the missions in Paraguay," Asúa, La ciencia de Mayo, 193, there was not always as Di Liscia well observed "interest in recognizing where such knowledge came from," for example, in the management of flora and fauna for medicinal purposes. See: Maria Di Liscia, Saberes, Terapias y Prácticas Médicas en Argentina (1750-1910) (Madrid: Consejo Superior de Investigaciones Científicas, 2002), 299. On this issue, it is recommended to see more in: Eliane Fleck and Mariana Joaquim, "Sobre os 'hijos del Paraguay' e as 'personas naturales inteligentes': uma análise dos relatos sobre saberes e práticas tradicionais indígenas no Paraguay Natural Ilustrado, de José Sánchez Labrador SJ. (1771-1776)," Memoria Americana-Cuadernos de Etnohistória 25 (2017): 29-46.

${ }_{94}$ Sabine Anagnostou and Fabian Fechner, "Historia Natural y Farmácia misionera entre los jesuítas en el Paraguay," in Saberes de la conversión. Jesuitas, indígenas e Impérios coloniales en las fronteras de la Cristiandad, ed. Guillermo Wilde, 175-190 (Buenos Aires: SB, 2011), 175.

${ }^{5}$ Sánchez Labrador, Paraguay Natural (ARSI), 1772, Tome II, Book I, 3.
} 
Following one of the premises of enlightened thought, the Jesuit makes sure to underline that his works was guided "by the usefulness of the news for the uses of human society, which will be of no little use in these Provinces of Paraguay, at least for their inhabitants to appreciate the productions of these lands, and to be able to make use of them." ${ }^{196}$ According to Argentinian historian Maria Silvia Di Liscia, ${ }^{97}$ the knowledge of American flora and fauna had a scientific basis for the members of the Society of Jesus, but also had a clear practical purpose that included both a need for survival and an economic bias. According to this author, wood, paints, food and medicines were sold to Europe, the preferred market in Platin America. Sánchez Labrador doesn't only highlight the diversity of plants, as well as their medicinal virtues in the chapter $L a$ utilidad, y usos de las Plantas (The usefulness and uses of Plants):

It should be noted that God, in the production of the Plants, adapted it to the various qualities of the Lands, of the seasons of the year, and of the climates, that from the forthcoming formation of the sun were to be derived. He did not put in all countries all the plants, nor did he produce them in all in the same state. Hence, America and Paraguay produce their own plants, distinct and generally diverse from those in Europe, Africa, and Asia. There is no other reason for this beautiful variety than the fact that the Author of all Nature had so wanted and arranged it. ${ }^{98}$

This aspect is once again underlined in the chapter titled Algunos Usos Utiles, y Curiosos (A Few Useful and Curious Uses), in which the Jesuit observes that:

In the discourse of the preceding Books in this Second Part of Paraguay Natural many utilities have been included, with which they provide their vegetable productions. Others, which required more Paper and time, were reserved for this Book. I have judged them to be extremely important as well as feasible in these Provinces, which abound with Materials and Ingredients to practice them. ${ }^{99}$

Regarding brazilwood (ybirapicta in Guarani), the Jesuit recognizes its wide use in dye extraction, highlighting the existence of two types of ybirapicta: ybirapicta guaçu and ybirapicta miri. As for the medicinal virtues of brazilwood, the Jesuit priest points out that these trees have a lot of oil and little essential salt, presenting an astringent quality, being, therefore, efficient to fortify the stomach and reduce high fevers, to cure serious inflammations in the eyes and fight jaundice. In the case of other species of wood existing in the vast region of the Jesuit Province of Paraguay, Sánchez Labrador also focuses on information on its use in construction-such as bridges, houses and churches - and in the manufacture of musical instruments, tools and sacred images. ${ }^{100}$ Among the forty eight plants that would be useful in construction, the Jesuit

${ }^{96}$ Ibid., Book VI, 358.

${ }^{77}$ Di Liscia, Saberes, Terapias y Prácticas Médicas.

${ }^{98}$ Sánchez Labrador, Paraguay Natural (ARSI), 1772, Tome II, Book I, 6.

${ }^{99}$ Ibid., Book VII, 462.

${ }^{100}$ In exile, Sánchez Labrador adopted a certain scientific vision "in the modern sense of the word... a 
highlights urundey (Astronium spp.), a species of the Fabaceae family, popularly known as pauferro (iron-wood) and native to the savanna regions of South America. Because it has a very resistant xylem, this wood was widely used in Jesuit reductions both in constructions and in the making of sacred images and turned works, deserving the following description: "Tall and very hard tree, it looks like iron. Its wood is used for Forks, Trapiches, and things that have to be under the ground or water. The works of lathe and alike come out very beautiful from it." ${ }^{101}$

This perception regarding the utilities of the native plants of Paraguay had already been announced by Sánchez Labrador in the Introduction of Tome I, in which he says:

on its surface it flaunts itself dressed in flowers, herbs, trees, fruits, whose stupendous multitude is distinguished with insatiable variety. But in such a magnificent Nature Theater, the one that marvelously shines is Divine Providence, who gave it being, and preserves it. . . . The Enlightenment of Natural Paraguay follows another more straight course with the Moderns . . . it can be seen as a summary of species, and knowledge, that can bring great profits. And true, that it is not the least important to save on expenses, to buy drugs, and materials carried from Europe, most of the time unsubstantiated, and always at high prices. Paraguay in its Productions is very sufficient in itself, and it can also supply (as from its famous Herbs) things that are very profitable to Peru, and to Spain. ${ }^{102}$

As we try to demonstrate in this article, Paraguay Natural Ilustrado is unequivocally a reference work for the reconstitution of the intellectual environment in which the Jesuit brothers and priests worked, in America and afterwards during their exile in Europe and to understand the effects of the American experience on the notions related to Botany in the Historias Naturales and Materias Médicas published in the eighteenth century.

\section{Final reflections}

The four volumes of Paraguay Natural have not yet been fully published. Among the factors that may justify its non-publication are the slow bureaucratic procedures for editorial censorshipboth civil and ecclesiastical — and the high printing costs, considering the number of pages of the manuscript. It should also be noted that, in 1776, the year of its completion, the Society

dynamic notion of sciences," and with a vigor that we can call scholarly, he described nature as something useful and "thoroughly classifiable by investigation," based on "a clear idea of progress in sciences." See: Kristin Huffine, "Raising Paraguay from Decline: Memory, Ethnography, and Natural History in the Eighteenth-Century Accounts of the Jesuit Fathers," in El saber de los jesuitas, historias naturales y el Nuevo Mundo, eds. Luís Millones Figueroa and Domingo Ledezma, 279-302 (Madrid: Iberoamericana, 2005), 295-7.

101 Sánchez Labrador, Paraguay Natural (ARSI), 1772, Tome II, Book II, 122.

102 Sánchez Labrador, Paraguay Natural (ARSI), 1771, Tome I, Introduction, IV-V. 
of Jesus had not yet been restored, that only happened in 1814 , which certainly contributed to the fact that such massive work had remained unknown to the researchers for many years.

The extensive work was addressed to other members of the Society of Jesus and, also, to other European naturalists, considered by the author as his peers. More than the concern with understanding by his potential readers, the descriptions and mentions made by Sánchez Labrador to other authorities in Botany had the evident purpose of giving credibility and legitimacy to his reports.

But, in addition to the undeniable influences that the authors, who he had contact with, exerted on him, during the period of his training and practice as a missionary, and later in Italy, his trajectory in the Americas is unequivocally present in Paraguay Natural, as we try to demonstrate in this article. The analysis effort we undertake is, as a result, due to the reconfiguration that the History of Science has experienced in the last decades with a view to the decentralization of "a Eurocentric model of reflection" and to the valorization of the "dynamics of negotiation between actors from various social groups and various spaces, to finally reject the diffusionist model linked to the hegemony of the production of 'science' from a center or a metropolis." By adopting this perspective and by privileging "intersections, pluridirectionality and multidimensionality of the productions of knowledge" in circulation, ${ }^{103}$ we seek to point to the evidence of construction and reconfiguration of scientific knowledge in the work Paraguay Natural.

The analysis of this work allows however, to also reflect on "the books that might have been written, and the contributions to knowledge that might have been made if exile had not happened." 104 This instigating provocation made by Peter Burke in his work Exiles and expatriates in the history of knowledge leads us to conjecture about the content and the form that the works of the Jesuit priest José Sánchez Labrador could have taken, had he remained in Platin America — working with the indigenous populations of the Jesuit Province of Paraguay —and therefore, far from the scientific advances of the eighteenth century, from the contacts he had with other exiled Jesuits and from the works he was able to consult in Ravenna. ${ }^{105}$ To this

103 Gaune and Romano, "Fragmentos de un mundo en tránsito," 141.

${ }_{104}$ Peter Burke, Exiles and expatriates in the history of knowledge, 1500-2000 (Lebanon NH: University Press of New England, 2017), 9.

105 For Sainz Ollero and colleagues and Furlong, Paraguay Natural was started in the Americas, but completed during exile in Italy. The references that Sánchez Labrador makes to the Diccionario razonado universal de historia natural del señor Bomare (Reasoned universal dictionary of natural history by Mr. Bomare), which began to be published in 1765 , seem to be an indication of this, because, according to him, it is unlikely that the Jesuit would have consulted this work by the French naturalist and pharmacist when he still was in the Americas, not only because of the difficulties of its circulation from Asunción, after a possible acquisition by the Procurator of the Society of Jesus, and by the isolation of the mission of Belén, where he was missioning, but also because, from the beginning of December 1766 to the beginning of August 1767, Sánchez Labrador was on a trip to the Missions of Chiquitos, and then he 
speculation, we could add yet another inevitable questioning, which concerns the effects of the confiscation of notes and, consequently, of triggering memories in the works that the Spanish Jesuit wrote about the thirty four years he lived in Platin America, and which can be observed, in part, in the erasures made in the body of the text, in the supplementary annotations inserted in the margins or in the footnotes of Paraguay Natural.

Regardless of the answers that we could give to these questions and the conditions that interfered in its writing, Paraguay Natural constitutes, without a doubt, a reference work for the reconstruction of the intellectual environment in which Jesuit brothers and priests were inserted in the missions among the indigenous peoples or in the colleges of Platin America, as well as in Europe from their exile, and, especially, for reflection on the effects of the American experience on the intellectual production of the Society of Jesus. ${ }^{106}$

\section{Competing interests}

The author has declared that no competing interests exist.

\section{Funding}

This article is a result of the research project "The healing arts in two unpublished Jesuit manuscripts from the eighteenth century," which counted with the support of the Conselho Nacional de Desenvolvimento Científico e Tecnológico (CNPq) and the Fundação de Amparo à Pesquisa do Estado do Rio Grande do Sul (FAPERGS) for its development.

was sent to Europe, along with other companions of the order.

106 About the suppression of the Society of Jesus in the eighteenth century see: Jeffrey Burson and Jonathan Wright, eds., The Jesuit Suppression in Global Context: Causes, Events, and Consequences (Cambridge: Cambridge University Press, 2015). 